\title{
Antibiotic resistance and prevalence of class 1 and 2 integrons in Escherichia coli isolated from two wastewater treatment plants, and their receiving waters (Gulf of Gdansk, Baltic Sea, Poland)
}

\author{
Ewa Kotlarska • Aneta Luczkiewicz • Marta Pisowacka • \\ Artur Burzyński
}

Received: 31 January 2014 / Accepted: 18 August 2014 / Published online: 29 August 2014

(C) The Author(s) 2014. This article is published with open access at Springerlink.com

\begin{abstract}
In this study, antimicrobial-resistance patterns were analyzed in Escherichia coli isolates from raw (RW) and treated wastewater (TW) of two wastewater treatment plants (WWTPs), their marine outfalls (MOut), and mouth of the Vistula River (VR). Susceptibility of $E$. coli was tested against different classes of antibiotics. Isolates resistant to at least one antimicrobial agent were PCR tested for the presence of integrons. Ampicillin-resistant E. coli were the most frequent, followed by amoxicillin/clavulanate (up to $32 \%$ ), trimethoprim/sulfamethoxazole (up to $20 \%$ ), and fluoroquinolone (up to $15 \%$ )-resistant isolates. Presence of class 1 and 2 integrons was detected among tested $E$. coli isolates with rate of $32.06 \%(n=84)$ and $3.05 \%(n=8)$, respectively. The presence of integrons was associated with increased frequency of resistance to fluoroquinolones, trimethoprim/sulfamethoxazole, amoxicillin/clavulanate, piperacillin/tazobactam, and presence of multidrug-resistance phenotype. Variable regions were detected in 48 class 1 and 5 class 2 integron-positive isolates. Nine
\end{abstract}

Responsible editor: Gerald Thouand

E. Kotlarska $(\bowtie) \cdot$ A. Burzyński

Genetics and Marine Biotechnology Department, Institute of

Oceanology of the Polish Academy of Sciences, Powstancow

Warszawy 55, 81-712 Sopot, Poland

e-mail: ewachec@iopan.gda.pl

A. Burzyński

e-mail: aburzynski@iopan.gda.pl

\section{A. Łuczkiewicz}

Department of Water and Wastewater Technology, Faculty of Civil and Environmental Engineering, Gdansk University of Technology, Narutowicza 11/12, 80-233 Gdansk, Poland

e-mail: ansob@pg.gda.pl

\section{Pisowacka}

Instituto Gulbenkian de Ciência, Rua da Quinta Grande 6,

2780-156 Oeiras, Portugal

e-mail: marta.pisowacka@gmail.com different gene cassette arrays were confirmed among sequenced variable regions, with predominance of $d f r A 1-a a d A 1, d f r A 17-$ aadA5, and aadA1 arrays. These findings illustrate the importance of WWTPs in spreading of resistance genes in the environment and the need for inclusion of at least monitoring efforts in the regular WWTP processes.

Keywords Escherichia coli - Wastewater treatment plant . Marine outfalls $\cdot$ Integrons $\cdot$ Gene cassettes $\cdot$ Antibiotic resistance

\section{Introduction}

Safe and economical way of wastewater disposal is an important problem requiring proper receiver-oriented management. Nowadays, wastewater treatment focuses mainly on parameters that may cause oxygen depletion and eutrophication of the receiving waters: organic matter, nitrogen, and phosphorus. Health aspects are considered only in terms of fecal contamination and evaluated only in bathing areas by monitoring fecal indicators (Escherichia coli and Enterococcus species). However, other important aspects of wastewater discharge are currently under debate. It is suspected that clinically relevant bacteria and mobile genetic elements can survive the wastewater treatment plant processes (Reinthaler et al. 2003; D'Costa et al. 2006; Łuczkiewicz et al. 2010) and be disseminated in the receiving waters (Iwane et al. 2001; Li et al. 2009; Czekalski et al. 2012). Additionally, human-associated bacteria are regarded as important vectors of gene transmission (D'Costa et al. 2006). Thus, domestic and municipal wastewater should be considered in global antibiotic resistance gene dissemination.

Mobile genetic elements play crucial role in spreading antimicrobial-resistance genes. Among them, integrons are suspected to be the most important (Stalder et al. 2012), since they are often associated with other mobile genetic elements, 
such as plasmids or transposons, and are detected in various environments and matrices (Rosser and Young 1999; Goldstein et al. 2001; Elsaied et al. 2007, 2011; Gillings et al. 2009; $\mathrm{Xia}$ et al. 2013). Integrons are widely distributed in gramnegative bacteria; however, recent studies indicate their presence also in gram-positive species (Xu et al. 2001, 2010). About $10 \%$ of bacterial genomes that have been partially or completely sequenced harbor this genetic element (Boucher et al. 2007). The spread of antimicrobial-resistance genes by integrons was extensively investigated primarily in clinical settings (Grape et al. 2003; Pan et al. 2006; Dubois et al. 2007). Nowadays, increased interest in their environmental role is observed (Elsaied et al. 2007; Gillings et al. 2009; Elsaied et al. 2011) and also reviewed by Stalder et al. (2012). Integrons consist of integrase (intl) gene, a recombination site $(a t t I)$ and one or two promoters (Recchia and Hall 1995). Based on the amino acid sequence of the IntI protein, five classes of integrons have been described (Cambray et al. 2010). Classes 1, 2, and 3 are the most common. Gene cassettes are captured through recombination between attI site of the integron and a 59-bp element ( $a t t C$ site) from the cassette. Gene cassettes associated to class 1-3 integrons often confer resistance to aminoglycoside and $\beta$-lactam antibiotics, chloramphenicol, trimetophrim, sulfonamides, spectinomycin and others (Partridge et al. 2009; Moura et al. 2009). They can also carry other adaptive genes associated with environmental stresses or open reading frames, coding hypothetical proteins of unknown function (Elsaied et al. 2007, 2011).

The objective of this study was to investigate antibioticresistance profiles in $E$. coli isolated from two local wastewater treatment plants (raw and treated wastewater samples), their marine outfalls located in the Gulf of Gdansk, the Baltic Sea (Poland), and from major tributary of the Baltic Sea-the Vistula River. In order to evaluate the role of the studied wastewater effluents and tributaries in dissemination of integrons and antibiotic resistance genes in anthropogenically impacted part of the Gulf of Gdansk, prevalence of class 1 and 2 integrons among $E$. coli isolates resistant to at least one antimicrobial agent was analyzed. The association between resistance or multiresistance to tested antimicrobials and presence of integrons in $E$. coli isolates was also studied. To assess the diversity of gene cassettes in integron-positive isolates, 35 selected amplicons representing variable region of integrons were sequenced and annotated.

\section{Materials and methods}

Sampling sites and samples collection

Altogether, 36 samples were analyzed. Samples of raw and treated wastewater (RW and TW, respectively) were taken from two local wastewater treatment plants (WWTPs) and from their marine outfalls (MOut) (Fig. 1). In both cases, treated wastewater is discharged by submarine collectors, about $2.5 \mathrm{~km}$ long and equipped with diffuser systems. The plants mainly treat municipal wastewater. Industrial wastewater and non-disinfected hospital wastewater consist about 10 and $0.2 \%$ of their daily inflow, respectively.

\section{WWTP "Gdansk-Wschod"}

WWTP Gdansk-Wschod works in a modified University of Cape Town (UCT) type system, with integrated effective removal of nitrogen, phosphorus, and carbon in anaerobic/anoxic/oxic zones fed with internal recycles (Tchobanoglous et al. 1991). The plant serves the population of about 570,000 people (population equivalent-700,000; the average daily flow$96,000 \mathrm{~m}^{3} /$ day). Marine outfall has been operated since 2001 . The flow-proportioned composite samples of raw (WRW) and treated wastewater (WTW) were taken from February to December 2011 (six samples of each type of wastewater were collected). Marine outfall (WMOut) sampling point was located in the Gulf of Gdańsk (54 $22^{\prime} 44.4^{\prime \prime} \mathrm{N} ; 18^{\circ} 52^{\prime} 40.8^{\prime \prime} \mathrm{E}$ ), and marine water was taken in April, June, August, and October 2011 (four samples in total were collected).

\section{WWTP “Gdynia-Debogorze”}

WWTP Gdynia-Debogorze treats wastewater in four-stage Bardenpho system at the biological stage of the plant, including primary and secondary anoxic reactors (Tchobanoglous et al. 1991). The average daily flow was $55,000 \mathrm{~m}^{3} /$ day, population equivalent-440,000. Treated wastewater has been discharged there by marine outfall since 2010. Raw (DRW) and treated wastewater (DTW) were taken as flow proportioned samples every 2 months from February to December 2011 (six samples of each type of wastewater were collected). Marine water samples (DMOut) were collected in the Puck Bay (54 37' 08.4" N; $18^{\circ} 33^{\prime} 28.8^{\prime \prime}$ E), in April, June, August, and October 2011 (four samples in total were collected).

\section{Mouth of the Vistula River}

Mouth of the Vistula River (VR) was sampled at the point located at $54^{\circ} 22^{\prime} 58.8^{\prime \prime} \mathrm{N} ; 18^{\circ} 58^{\prime} 04.8^{\prime \prime}$ E. Samples of surface water were taken once a month in April, June, August, and October 2011 (four samples in total were taken).

Enumeration and isolation of $\boldsymbol{E}$. coli

$E$. coli detection in wastewater and marine water samples was carried out according to APHA (1998) by means of membrane filtration, using membrane fecal coliform (mFC) agar (Merck) and an appropriate dilution (treated wastewater) or 
Fig. 1 Sampling sites: raw (WRW) and treated (WTW) wastewater, as well as marine outfall (WMOut) of WWTP Gdansk-Wschod; raw (DRW) and treated (DTW) wastewater, as well as marine outfall (DMOut) of WWTP Gdynia-Debogorze. $V R$ mouth of the Vistula River

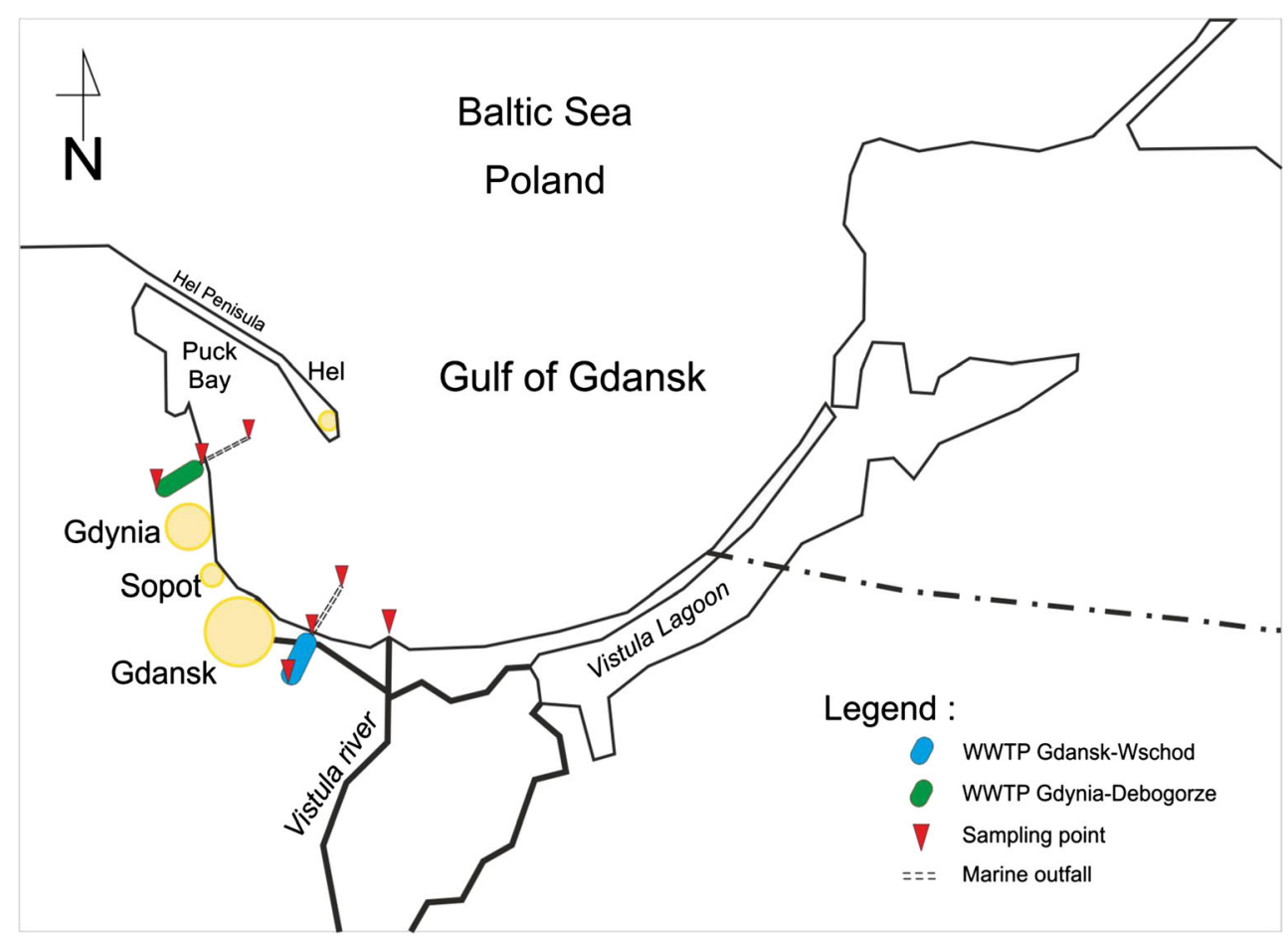

concentration (marine and riverine water) of collected samples. The enumeration was conducted for wastewater samples in triplicate (according to recommendations of APHA (1998) for water and wastewater samples), and for other samples, due to suspected low number of $E$. coli, in sixfold repetition. For quality control, E. coli ATCC 25922 strain was used. This strain forms blue and dark blue colonies on mFC agar while other organisms form gray to cream colonies. For identification and antimicrobial susceptibility tests, $5-15$ blue bacterial colonies (presumptive $E$. coli) from each of the membrane filters were selected and preserved at minus $80{ }^{\circ} \mathrm{C}$ in nutrient broth (beef extract, $3 \mathrm{~g} / \mathrm{L}$, peptone $5 \mathrm{~g} / \mathrm{L}$; Becton, Dickinson and Company), supplemented with $15 \%$ glycerol.

Identification and antimicrobial susceptibility tests

The identification and drug susceptibility of presumptive E. coli isolates were determined by the Phoenix Automated Microbiology System (Phoenix AMS, BD) according to the manufacturer's instruction. The susceptibility tests, based on microdilution, were carried out against 17 antimicrobial agents: amikacin (AN), gentamicin (GM), tobramycin (NN), imipenem (IPM), meropenem (MEM), cefazolin (CZ), cefuroxime (CXM), ceftazidime (CAZ), cefotaxime (CTX), cefepime (FEP), aztreonam (ATM), ampicillin (AM), amoxicillin/clavulanate (AMC), piperacillin/tazobactam (TZP), trimethoprim/sulfamethoxazole (STX), ciprofloxacin (CIP), and levofloxacin (LVX) together with screening for extended-spectrum $\beta$-lactamases (ESBL) production. Antimicrobial susceptibility was categorized according to EUCAST
(2011). All ESBL-producing isolates were confirmed using the double-disk synergy test according to EUCAST (2011). The multidrug-resistance (MDR) phenotype was defined as simultaneous resistance to antimicrobial agents representing 3 or more categories, according to Magiorakos et al. (2012). E. coli ATCC 25922 and Pseudomonas aeruginosa ATCC 27853 were used as reference strains. Only the isolates confirmed as $E$. coli were further analyzed-774 isolates in total: 306 from WWTP Gdansk-Wschod (80 from WRW, 134 from WTW, and 92 from WMOut), 343 from WWTP GdyniaDebogorze (124 from DRW, 102 from DTW, and 117 from DMOut), and 125 from the mouth of the Vistula River (VR).

DNA extraction

Total DNA was obtained from several bacterial colonies, freshly grown on LB agar (tryptone $10 \mathrm{~g} / \mathrm{L}$, yeast extract $5 \mathrm{~g} / \mathrm{L}$, sodium chloride $10 \mathrm{~g} / \mathrm{L}$, agar $15 \mathrm{~g} / \mathrm{L}$; Becton, Dickinson and Company). Bacterial suspensions were prepared in distilled water and subsequently boiled in a water bath for $5 \mathrm{~min}$. Cell debris was centrifuged at 13,000 rpm for $5 \mathrm{~min}$, and the resulting supernatant was used as a template for all PCR assays.

Identification and characterization of integrons

Isolates resistant to at least one antimicrobial agent $(n=262)$ were tested for the presence of integrons. These included 130 isolates from WWTP Gdansk-Wschod (35 from WRW, 49 from WTW, and 46 from WMOut), 103 from WWTP 
Gdynia-Debogorze (47 from DRW, 35 from DTW, and 21 from DMOut), and 29 from the mouth of the Vistula River (VR).

The presence of integrons was detected by PCR amplification of the integrase gene intII (for class 1 integrons) and intI2 (for class 2 integrons) using previously described primers (Kraft et al. 1986; Falbo et al. 1999; Mazel et al. 2000). Additionally, the presence of sull and qacE $\Delta 1$ genes, which are usually associated with integrons (Stokes and Hall 1989; Paulsen et al. 1993), was also checked. In order to determine the size of the variable gene cassette regions in integronpositive isolates, we used previously described primer sets 5CS-3CS and hepF-hepR (for class 1 and class 2 variable region, respectively) (Levesque et al. 1995; White et al. 2001). All primers used are shown in Table 1. All PCR reactions were carried out in T1 thermal cycler (Biometra $\mathrm{GmbH}$, Goettingen, Germany) using nucleotides and buffers purchased from A\&A Biotechnology. For detection of integrase genes, sull and qacE $\Delta 1$ genes Taq polymerase was used (A\&A Biotechnology). The temperature profile for integrase, sul1, and qacE $\Delta 1$ genes amplification was as follows: initial denaturation ( $94{ }^{\circ} \mathrm{C}$ for $9 \mathrm{~min}$ ), followed by 30 cycles of denaturation $\left(94^{\circ} \mathrm{C}\right.$ for $30 \mathrm{~s}$ ), annealing (30 s at temperature indicated in Table 1$)$, and extension $\left(72^{\circ} \mathrm{C}\right.$ for $\left.1 \mathrm{~min}\right)$; and then a final extension $\left(72{ }^{\circ} \mathrm{C}\right.$ for $\left.10 \mathrm{~min}\right)$. Selected class 1 and 2 integrase amplicons were sequenced and served as positive controls in further PCR experiments. Sequences of integrase genes from these positive controls were deposited in GenBank under accession numbers KM219981 and KM219982. E. coli DH5 $\alpha$ strain served as negative control during PCR experiments.

In order to determine the size of variable regions of integrons, gene cassette amplifications were performed using
Phusion $^{\mathrm{TM}}$ polymerase (Thermo Fisher Scientific), and amplification was carried out as follows: initial denaturation $\left(98^{\circ} \mathrm{C}\right.$ for $30 \mathrm{~s})$, followed by 24 cycles of denaturation $\left(98^{\circ} \mathrm{C}\right.$ for $10 \mathrm{~s})$, annealing $\left(63^{\circ} \mathrm{C}\right.$ for $\left.30 \mathrm{~s}\right)$, elongation $\left(72^{\circ} \mathrm{C}\right.$ for $\left.6 \mathrm{~min}\right)$, and final elongation $\left(72{ }^{\circ} \mathrm{C}\right.$ for $\left.10 \mathrm{~min}\right)$. PCR products were analyzed by electrophoresis on a $1 \%$ agarose gel in $1 \times$ TAE buffer (Sambrook and Russell 2001) and stained with ethidium bromide $\left(0.5 \mu \mathrm{g} \mathrm{mL}^{-1}\right)$, visualized under UV light, and documented using Vilber Lourmat image acquisition system. Size of the PCR products was compared with 1-kb DNA Ladder (Thermo Scientific) in Bio1D software (Vilber Lourmat, Marne-la-Vallée, France).

\section{Sequencing of gene cassette arrays}

Selected amplicons representing various size classes of integrons were sequenced using ABI PRISM BigDye Terminator cycle sequencing with forward and reverse primers (for class 1, 5CS-3CS, and for class 2 integrons, hepF-hepR) (Macrogen, Korea). Raw sequence reads were assembled using pregap4 and gap4 programs from Staden Package (Bonfield et al. 1995). High-quality consensus sequences were extracted from the assembly and afterward analyzed. DNA sequence analysis and gene cassette array annotations were performed using BLAST algorithm against INTEGRALL database (Moura et al. 2009). Sequences were deposited in GenBank under accession numbers KJ192400-KJ192434.

Statistical analysis

Significance of differences between antibiotic-resistance rates in all studied samples was determined using Fisher's exact

Table 1 Primers used in this study

\begin{tabular}{|c|c|c|c|c|}
\hline Target & Primer sequences $\left(5^{\prime}-3^{\prime}\right)$ & $\begin{array}{l}\text { PCR product } \\
\text { size (bp) }\end{array}$ & $\begin{array}{l}\text { PCR annealing } \\
\text { temperature }\left({ }^{\circ} \mathrm{C}\right)\end{array}$ & Reference \\
\hline intI1 & $\begin{array}{l}\text { Int1AF: CCT CCC GCA CGA TGA TC } \\
\text { Int1AR: TCC ACG CAT CGT CAG GC }\end{array}$ & 280 & 55 & Kraft et al. 1986 \\
\hline intII & $\begin{array}{l}\text { Int1BF: GAA GAC GGC TGC ACT GAA CG } \\
\text { Int1BR: AAA ACC GCC ACT GCG CCG TTA }\end{array}$ & 1,201 & 65 & Falbo et al. 1999 \\
\hline intI2 & $\begin{array}{l}\text { Int2AF: TTA TTG CTG GGA TTA GGC } \\
\text { Int2AR: ACG GCT ACC CTC TGT TAT C }\end{array}$ & 233 & 50 & Goldstein et al. 2001 \\
\hline intI2 & $\begin{array}{l}\text { Int2BF: GTA GCA AAC GAG TGA CGA AAT G } \\
\text { Int2BR: CAC GGA TAT GCG ACA AAA AGG T }\end{array}$ & 788 & 65 & Mazel et al. 2000 \\
\hline $\begin{array}{l}\text { Class } 1 \text { integron } \\
\text { variable region }\end{array}$ & $\begin{array}{l}\text { 5CS: GGC ATC CAA GCA GCA AG } \\
\text { 3CS: AAG CAG ACT TGA CCT GA }\end{array}$ & Variable & 63 & Levesque et al. 1995 \\
\hline $\begin{array}{l}\text { Class } 2 \text { integron } \\
\text { variable region }\end{array}$ & $\begin{array}{l}\text { hepF: CGG GAT CCC GGA CGG CAT GCA } \\
\text { CGA TTT GTA } \\
\text { hepR: GAT GCC ATC GCA AGT ACG AG }\end{array}$ & Variable & 63 & White et al. 2001 \\
\hline sul 1 & $\begin{array}{l}\text { Sul1F: ATG GTG ACG GTG TTC GGC ATT CTG A } \\
\text { Sul1R: CTA GGC ATG ATC TAA CCC TCG GTC T }\end{array}$ & 800 & 55 & Grape et al. 2003 \\
\hline$q a c \mathrm{E} \Delta 1$ & $\begin{array}{l}\text { qacF: ATC GCA ATA GTT GGC GAA GT } \\
\text { qacR: CAA GCT TTT GCC CAT GAA GC }\end{array}$ & 225 & 55 & Stokes and Hall 1989 \\
\hline
\end{tabular}


test. The frequencies of resistance to particular antimicrobials and presence of MDR phenotype in integron-positive and integron-negative isolates were compared with Fisher's exact test. The differences in antimicrobial-resistance ranges, expressed as the number of antimicrobials or antimicrobial classes, to which the isolates were resistant, were compared with Mann-Whitney $U$ test. $P<0.05$ was considered to indicate statistical significance. Calculations were performed with Statistica 7 software (StatSoft).

\section{Results and discussion}

\section{E. coli number}

In this study, the impact posed by treated wastewater on the receiving waters was evaluated using $E$. coli isolates. The number of $E$. coli in raw wastewater (WRW, DRW) varied between $0.7 \times 10^{7}$ and $23 \times 10^{7}$ colony-forming unit (CFU) per $100 \mathrm{~mL}$ (Table 2). Both WWTPs demonstrated high efficiency in E. coli removal (over $99 \%$ ), although occasionally exceeding $10^{5} \mathrm{CFU}$ per $100 \mathrm{~mL}$ in effluents (WTW, DTW). In the case of their marine outfalls (WMOut, DMOut), as well as the mouth of the Vistula River (VR), only single E. coli cells $(<100 \mathrm{CFU}$ per $100 \mathrm{~mL})$ were detected, indicating that the water quality was better than the "excellent" according to the New Bathing Water Directive 2006/7/EC.

\section{E. coli with antibiotic and multiple-antibiotic resistance}

One of the objectives of this study was to compare the antimicrobial susceptibility among $E$. coli of wastewater (WRW, WTW and DRW, DTW), marine water (WMOut and DMOut), and river mouth origin (VR). In total, 774 E. coli isolates were investigated. Regardless of the sampling point, high prevalence of AM-resistant E. coli was detected (Fig. 2). The resistance rate varied, however, in broad range, from $13 \%$ in VR to $47 \%$ in WMOut. The prevalence of penicillinresistance among $E$. coli was also reported in clinical settings (ECDC 2011), as well as in different environmental compartments ( $\mathrm{Li}$ et al. 2009). The resistance rate, however, varied significantly. In most European countries since 2007, the resistance to aminopenicillins has exceeded $40 \%$ among
E. coli of clinical origin (in Poland between 54 and $65 \%$ ) (ECDC 2011). The current state of knowledge suggests that the spread of antibiotic resistance is mainly due to selective pressure (ECDC/EMEA 2009; Martinez 2008; Baquero et al. 2009; Harada and Asai 2010; Andersson and Hughes 2012). Thus, these findings are not surprising - penicillins are the most often used antibacterial agents (ATC group J01) in the community (outside the hospital) in Europe (ECDC 2010). Also, broad-spectrum penicillins (J01CA) were the most consumed antibiotics in Poland-about five defined daily doses (DDD) per 1,000 inhabitants and per day, followed by combination of penicillins with $\beta$-lactamase inhibitors (J01CR) about 3.5 DDDs per 1,000 inhabitants and per day in 2010 (ECDC 2010). In the present study, the prevalence of AMresistant $E$. coli, followed by isolates resistant to combination of amoxicillin (penicillins) and clavulanate ( $\beta$-lactamase inhibitor) (up to $32 \%$ ), seems to mirror the usage trends. Slightly lower resistance rates were noted to trimethoprim/ sulfamethoxazole (5-20\%) and fluoroquinolones (5-15\%) (Fig. 2). Trimethoprim/sulfamethoxazole and fluoroquinolones are recommended as first-line drugs for uncomplicated urinary tract infections (UTIs). Recently, however, fluoroquinolones are increasingly being used instead of trimethoprim/sulfamethoxazole (Kallen et al. 2006). In consequence, selective pressure together with plasmid-mediated quinolone-resistance (PMQR) mechanisms has probably accelerated the rate of fluoroquinolone resistance spread among uropathogens (Gupta et al. 2005). In Europe, among clinical uropathogen E. coli strains, fluoroquinolones resistance exceeded $20 \%$ (in Poland up to $26 \%$ in 2010) (ECDC 2011). Quinolone and fluoroquinolone resistance is being increasingly reported around the world (Poirel et al. 2012). Principal mechanisms of resistance to those antibiotics are chromosome-encoded. However, the emergence of plasmid-mediated resistance is a major threat to public health (Mammeri et al. 2005; Poirel et al. 2012; Mokracka et al. 2012).

Among E. coli strains isolated from feces of mallards, herring gulls, and waterbirds on the Polish coast of the Baltic Sea, plasmid-encoded quinolone resistance associated with the $q n r S$ gene was noted (Literak et al. 2010). Resistance to nalidixic acid was most frequent (together with resistance to tetracycline, followed by resistance to aminoglycosides and ampicillin) among heterotrophic marine bacteria isolated from Baltic Sea water samples (Moskot et al. 2012).

Table 2 Average number of E. coli (CFU $100 \mathrm{~mL}^{-1}$ ) in raw (WRW, DRW) and treated wastewater (WTW, DTW) as well as in marine outfalls (WMOut, DMOut), and mouth of the Vistula River (VR) (minimal and maximal number of E. coli in brackets)

\begin{tabular}{|c|c|c|c|c|c|c|}
\hline \multicolumn{3}{|l|}{ Gdansk-Wschod } & \multicolumn{3}{|l|}{ Gdynia-Debogorze } & \multirow[t]{2}{*}{ Vistula River (VR) } \\
\hline WRW & WTW & WMOut & DRW & DTW & DMOut & \\
\hline $10.7(0.7-23) \times 10^{7}$ & $2.4(0.1-6.1) \times 10^{5}$ & $43(30-60)$ & $8.5(0.7-13) \times 10^{7}$ & $2.1(0.8-3.1) \times 10^{5}$ & $22(2-32)$ & $21(3-25)$ \\
\hline
\end{tabular}


Rising trends are also observed among clinical E. coli resistant to third-generation cephalosporins and aminoglycosides. In this study, such resistance was reported only occasionally, while resistance to clinically relevant carbapenems (IPM and MEM) was not detected (Fig. 2). However, three isolates from raw wastewater (one from WRW and two from DRW) and two isolates from marine outfall (WMOut) produced ESBL. According to the ECDC surveillance report (2011) and numerous other reports (Pitout et al. 2005; Perez et al. 2007; Guenther et al. 2011; Liebana et al. 2013), the prevalence of ESBL-producing isolates has been on a continuous increase during the last decade. The majority of ESBLs
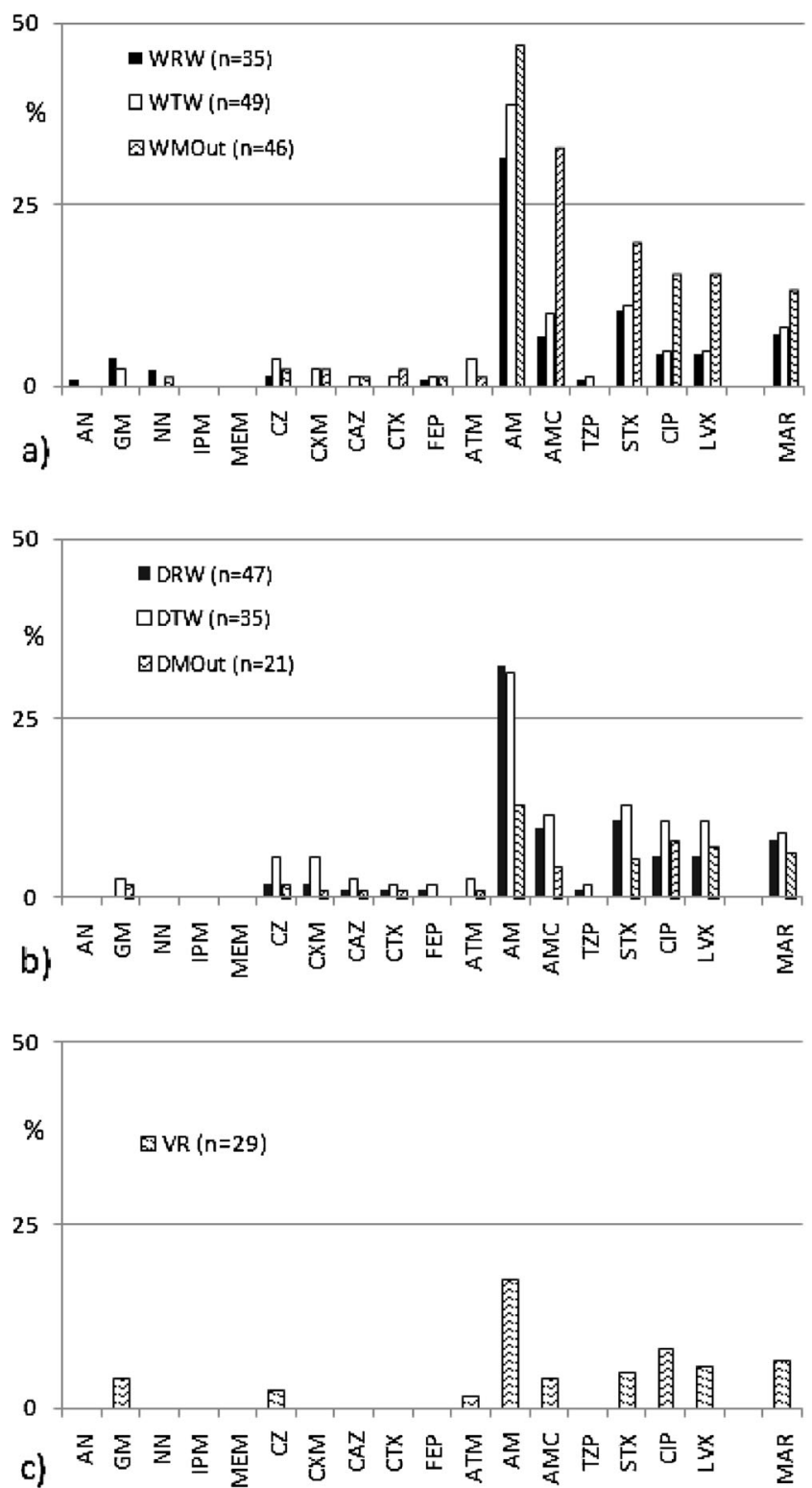

Fig. 2 Antibiotic susceptibility of $E$. coli isolates from raw wastewater (WRW, DRW), treated wastewater (WTW, DTW), and marine outfalls (WMOut, DMOut) of a WWTP Gdansk-Wschod and b WWTP Gdynia-Debogorze, respectively, as well as from $\mathbf{c}$ the mouth of the Vistula River $(V R)$ are isolated from human clinical samples; however, they were also detected in wastewater and human-impacted environmental compartments (e.g., Galvin et al. 2010; Reinthaler et al. 2010; Hartmann et al. 2012; Chagas et al. 2011; Korzeniewska et al. 2013). ESBL-producing isolates of domestic and wild animal origin were also reported (Smet et al. 2010; Guenther et al. 2011; Tausova et al. 2012; Liebana et al. 2013). E. coli isolates with MDR phenotype were detected in all samples, comprising from $6 \%$ (in VR and DMOut) to $13 \%$ (in WMOut) of isolates. The positive selection of bacteria with resistance patterns, previously described in wastewater processes (Łuczkiewicz et al. 2010; Ferreira da Silva et al. 2007; Novo and Manaia 2010), was also observed in this study for both of the WWTPs. Resistance rate to AMC, STX, CIP, and LVX noted for E. coli isolated from treated wastewater (WTW and DTW) was higher than that observed in corresponding raw wastewater (WRW and DRW), but the differences were not statistically significant (in Fisher's exact test). In the case of narrow- (CZ, CXM) and extendedspectrum (CAZ, CTX, FEP) cephalosporins, as well as TZP, the results were not evaluated due to the low number of resistant isolates. Interestingly, statistically significant rising trends (Fisher's exact test, $P<0.05$ ) were noted for AMC-, STX-, CIP-, and LVX-resistant E. coli, as well as for E. coli with MDR pattern, isolated from marine outfall WMOut and corresponding treated wastewater (WTW). Such phenomenon was not observed for treated wastewater of WWTP GdyniaDebogorze (DTW) and its marine outfall (DMOut). Resistance rates among $E$. coli from DMOut were comparable to those detected in the mouth of the Vistula River (VR). The differences between observed local impact caused by marine outfalls may be partly explained by differences in their operation time. Treated wastewater from WWTP Gdansk-Wschod was discharged via marine outfall (WMOut) for the last 12 years, while marine outfall of WWTP Gdynia-Debogorze (DMOut) has been operating for 2 years only. However, further detailed analyses are needed to understand better the impact of resistance genes in these water ecosystems.

Among 37 and $34 \%$ of $E$. coli isolated from raw wastewater samples (WRW and DRW, respectively), resistance to at least one of the antimicrobial agents was noted (Fig. 3). In both WWTP effluents, the resistance rate increased to $44 \%$ for WTW and $38 \%$ for DTW. In the case of marine outfalls rising, trends were observed only for WMOut ( $47 \%$ of E. coli isolates showed resistance), while resistance rate observed in DMOut was significantly lower (18\%) and similar to that noted for mouth of the VR (23\%).

As indicated in this study, human-associated bacteria with resistance and MDR phenotypes can survive wastewater treatment processes and be disseminated in the receiving waters. Since it is believed that WWTPs represent hotspots for horizontal gene transfer (Mokracka et al. 2012; Ma et al. 2013), we decided to assess the prevalence of class 1 and 2 integrons 


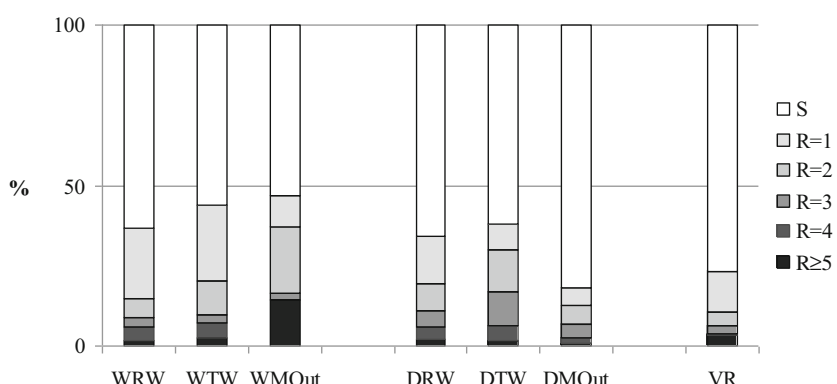

Fig. 3 Susceptibility of $E$. coli isolates to increasing number of antimicrobial agents ( $S$ sensitive to all, $R l-R \geq 5$ resistant from 1 to 5 and more antimicrobial agents)

among antimicrobial-resistant E. coli isolated during this study.

Class 1 and 2 integrons in antimicrobial-resistant $\boldsymbol{E}$. coli

Since integrons have been associated with antibioticresistance capture and dissemination, in this study, the integron presence in $E$. coli isolates resistant to at least one antimicrobial agent was tested. In general, presence of class 1 and 2 integrons was detected in E. coli of $32.06 \%(n=84)$ and $3.05 \%(n=8)$, respectively. Both classes of integrons were detected in one isolate $(0.38 \%)$. Other authors reported smaller amounts of integron-positive isolates in wastewater environments, but in these reports, often all Enterobacteriaceae or Aeromonadaceae isolates were taken under consideration (e.g., Koczura et al. 2012; Moura et al. 2012). Nevertheless, similar frequencies of integron-bearing $E$. coli of animal, human, and wastewater origin were noted (Cocchi et al. 2007; Vinue et al. 2008). Xia et al. (2013) reported class 2 integrons in $8 \%$ among antimicrobial-resistant gram-negative bacteria isolated from wastewater environments in China. In our study, we did not check clonal relatedness of the isolates; thus, it could bias the results concerning prevalence of integrons. However, similar (30.8 and $1 \%$ for class 1 and 2, respectively) (Kang et al. 2005) or even higher (85.6 and $3.6 \%$ for class 1 and 2, respectively) (Su et al. 2006) prevalence of integrons in E. coli from clinical samples was recorded. In those studies, only selected strains showing the same gene cassette patterns were checked for clonal relatedness using PFGE patterns or ERIC-PCR, revealing distinct patterns; thus, little clonal relatedness between studied strains was stated (Kang et al. 2005; Su et al. 2006).

In raw wastewater, WRW and DRW, class 1 integrons were detected in 28.6 and $38.3 \%$ of resistant $E$. coli, respectively, whereas in treated wastewater, WTW and DTW, in 26.5 and $37.1 \%$ of isolates, respectively. In the isolates collected from marine outfalls, WMOut and DMOut, class 1 integrons were present in 29 and $37.1 \%$ of resistant isolates respectively, while in the mouth of the Vistula River (VR) in $27.6 \%$ of isolates.

Class 2 integrons were significantly less frequent. They were detected only in raw wastewater obtained from WWTP Gdynia-Debogorze (DRW) (one isolate-2.1\%), as well as in the treated wastewater of WWTP Gdansk-Wschod (WTW) (four isolates-8.2\%). In marine outfalls of both WWTPs, two isolates with class 2 integron were isolated (one isolate from each of the sampling points). Also, in the mouth of the VR, class 2 integron was detected only in one isolate. Additionally, only in this particular isolate (isolate O5 5017), integrons from both classes were present together (Fig. 4, Table 2).

Among 84 isolates positive for intIl gene, there were 16 isolates, in which only one pair of primers was successful in amplification of intI1 gene (with product size of $288 \mathrm{bp}$, Table 1). These isolates were nonetheless considered as intII positive because they gave positive results with primers designed to amplify variable region of class 1 integron. Among all class 2 integron-positive isolates $(n=8)$, intI 2 gene was amplified with both primers designed for this integrase gene (Table 1).

Association between antibiotic resistance, MDR phenotype, and integrons in $\boldsymbol{E}$. coli isolates

Among the integron-positive isolates, the highest resistance frequency was noted for ampicillin, amoxicillin/clavulanate, trimethoprim/sulfamethoxazole, and fluoroquinolones. Integron-negative isolates were also most frequently resistant to ampicillin, amoxicillin/clavulanate, and fluoroquinolones. Resistance to imipenem and meropenem was not observed in
Fig. 4 Presence of class 1 and 2 integrases in antimicrobialresistant $E$. coli isolated from raw wastewater ( $W R W$ and $D R W$ ), treated wastewater $(W T W$ and $D T W$ ), marine outfalls of WWTPs (WMOut and DMOut), and mouth of the Vistula River $(V R)$

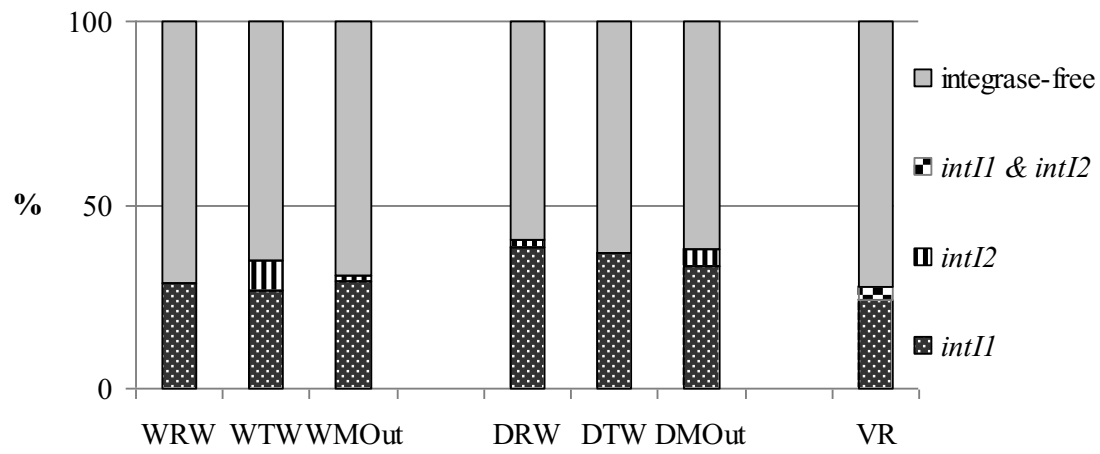


Table 3 Characteristics of integron-bearing E. coli isolates isolated from WWTP "Gdansk-Wschod" and WWTP "Gdynia-Debogorze" (raw wastewater: WRW and DRW; treated wastewater: WTW and DTW), and WWTPs marine outfalls (WMOut and DMOut) and also from mouth of the Vistula River (VR)
Integron variable regions

Size of amplicon Gene cassette array (bp)
WRW (raw wastewater from "Gdansk-Wschod" WWTP)

$\begin{array}{lllll}\text { GCK } 27 & 1 & + & + & 2 \\ \text { GCK } 140 & 1 & + & + & 1 \\ \text { GCK } 141 & 1 & + & + & 2 \\ \text { GCK } 149 & 1 & + & + & 3 \text { (MDR) } \\ \text { GCR } 150 & 1 & + & + & 3 \text { (MDR) }\end{array}$

WTW (treated wastewater from "Gdansk-Wschod" WWTP)

$\begin{array}{lllll}\text { WCO } 102 & 2 & - & - & 3 \text { (MDR) } \\ \text { GCO } 54 & 2 & - & - & 3 \text { (MDR) } \\ \text { GCO } 55 & 1 & + & + & 1 \\ \text { GCO } 181 & 1 & + & + & 1 \\ \text { GCO } 183 & 1 & + & + & 3 \text { (MDR) } \\ \text { WCUV 522 } & 1 & + & + & 3 \text { (MDR) } \\ \text { GCO } 175 & 1 & + & + & 2 \\ \text { WCO } 3 & 1 & + & + & 1 \\ \text { GCO } 164 & 1 & + & + & 4 \text { (MDR) } \\ \text { GCO } 187 & 1 & + & + & 1 \\ \text { GCO } 188 & 1 & + & + & 1 \\ \text { WCUVO 502 } & 1 & + & + & 1 \\ \text { WCUV 523 } & 1 & + & + & 2\end{array}$

WMOut (marine outfall of "Gdansk-Wschod" WWTP)

$\begin{array}{lllll}\text { WWDC 701 } & 1 & - & + & 2 \\ \text { WWDC 719 } & 1 & + & + & 4 \text { (MDR) } \\ \text { WWDC 727 } & 2 & - & - & 6 \text { (MDR, ESBL) } \\ & & & & \\ \text { WWDC 743 } & 1 & + & + & 2 \\ \text { WWDC 755A } & 1 & + & + & 4 \text { (MDR) } \\ \text { WWDC 755B } & 1 & + & + & 4 \text { (MDR) } \\ \text { WWDC 762A } & 1 & + & + & 4 \text { (MDR) } \\ \text { WWDC 762B } & 1 & + & + & 4 \text { (MDR) } \\ \text { WWDC 763 } & 1 & + & + & 4 \text { (MDR) } \\ \text { WWDC 817 } & 1 & + & + & 2 \\ \text { WWDC 829 } & 1 & + & + & 7 \text { (MDR, ESBL) } \\ \text { WWDC 845A } & 1 & & & 4 \text { (MDR) }\end{array}$

DRW (raw wastewater from "Gdynia-Debogorze" WWTP)

$\begin{array}{lllll}\text { BMK 231 } & 1 & + & + & 3 \text { (MDR) } \\ \text { BMK 236 } & 1 & + & + & 2 \\ \text { BMS 512 } & 1 & + & + & 3 \text { (MDR) } \\ \text { BMS 606 } & 1 & + & + & 3 \text { (MDR) } \\ \text { BMK 639 } & 1 & + & + & 2 \\ \text { BMS 710 } & 1 & + & + & 7 \text { (MDR, ESBL) } \\ \text { BMS 719 } & 1 & + & + & 4 \text { (MDR) } \\ \text { BMK 834 } & 1 & + & + & 2 \\ \text { BMS 2009 } & 1 & + & + & 2\end{array}$

AM STX
GM
AM STX
CZ CXM AM STX
AM AMC STX

AM AMC STX

AM AMC STX

AM

STX

AM STX CIP LVX

AM STX GM NN

AM STX

AM

AM STX CIP LVX GM

CIP LVX

AM

$\mathrm{AM}$

AM STX

AM STX

AM AMC STX CIP LVX

CZ CXM CAZ CTX FEP ATM AM AMC STX

AM STX

AM AMC STX CIP LVX

AM AMC STX CIP LVX

AM AMC STX CIP LVX

AM AMC STX CIP LVX

AM AMC STX CIP LVX

STX CIP LVX

CZ CXM CAZ CTX FEP

AM AMC STX CIP LVX NN

AM AMC STX CIP LVX

AM STX CIP LVX
AM STX
AM AMC STX
AM STX CIP LVX
AM STX
CZ CXM CAZ CTX FEP
$\quad$ ATM AM AMC STX CIP LVX
AM AMC STX GM
CIP LVX GM
AM STX

$\begin{array}{ll}1,600 & \text { dfrA17-aadA5 } \\ 1,500 & \text { dfrA1-aadA1 } \\ 1,600 & \text { dfrA1-aadA1 } \\ 1,650 & \text { NT } \\ 1,550 & \text { NT }\end{array}$

2,200

2,300

1,000

1,500

1,500

1,550

1,450

950

1,550

1,500

1,600

1,000

1,500

650

1,500

2,500

1,550

1,450

1,450

2,000

2,000

1,700

2,000

1,800

1,700

1,550

1,600

1,900

1,550

1,800

1,500

1,600

1,000

1,900

dfrA1-sat2-aadA1
dfrA1-sat2-aadA1
aadA1
dfrA1-aadA1
dfrA1-aadA1
dfrA17-aadA5
NT
NT
NT
NT
NT
NT
NT

dfrA7

dfrA1-aadA1

dfrA1-sat2-aadA1 ${ }^{\mathrm{a}}$

dfrA17-aadA5

NT

NT

NT

NT

NT

NT

NT

NT

dfrA1-aadA1

dfrA17-aadA5

bla $a_{\mathrm{OXA30}-a a d A 1}$

dfrA17-aadA5

dfrA12-orfF-aadA2

dfrA1-aadA1

dfrA17-aadA5

aadA1

dfrA12-orfF-aadA2 
Table 3 (continued)

\begin{tabular}{|c|c|c|c|c|c|c|c|}
\hline \multirow[t]{2}{*}{ Isolate no. } & \multirow[t]{2}{*}{ Class of integron } & \multirow[t]{2}{*}{ sull } & \multirow[t]{2}{*}{$q a c \mathrm{E} \Delta 1$} & \multicolumn{2}{|c|}{ Antimicrobial resistance tested } & \multicolumn{2}{|c|}{ Integron variable regions } \\
\hline & & & & No. of resistances & Resistance phenotype & $\begin{array}{l}\text { Size of amplicon } \\
\text { (bp) }\end{array}$ & Gene cassette array \\
\hline BMK 2011 & 1 & + & + & 3 (MDR) & AM AMC STX & 1,900 & dfrA12-orfF-aadA2 \\
\hline BMS 4003 & 1 & + & + & 2 & AM STX & 1,500 & dfrA1-aadA1 \\
\hline BMK 4016 & 1 & + & + & 2 & AM STX & 1,500 & dfrA1-aadA1 \\
\hline BMK 26 & 1 & + & + & 3 (MDR) & AM AMC TZP & 1,950 & NT \\
\hline \multicolumn{8}{|c|}{ DTW (treated wastewater from “Gdynia-Debogorze" WWTP) } \\
\hline BMO 244 & 1 & + & + & 4 (MDR) & AM AMC STX TZP & 1,500 & dfrA1-aadA1 \\
\hline BMO 645 & 1 & + & + & 2 & AM STX & 700 & dfrA5 \\
\hline BMO 843 & 1 & + & + & 1 & $\mathrm{AM}$ & 1,000 & aadAl \\
\hline BMO 3023 & 1 & + & + & 2 & AM STX & 1,550 & dfrAl-aadA1 \\
\hline BMO 4023 & 1 & + & + & 1 & $\mathrm{AM}$ & 1,000 & aadAl \\
\hline BMO 241 & 1 & + & + & 3 (MDR) & AM STX CIP LVX & 2,500 & NT \\
\hline BMO 5022 & 1 & + & + & 3 (MDR) & AM STX CIP LVX & 2,000 & NT \\
\hline DCUV 14 & 1 & + & + & 2 & AM STX & 1,600 & NT \\
\hline DCUV 105 & 1 & + & + & 3 (MDR) & AM AMC STX & 1,000 & NT \\
\hline \multicolumn{8}{|c|}{ DMOut (marine outfall of “Gdynia-Debogorze” WWTP) } \\
\hline R1 3110 & 1 & + & + & 2 & AM STX & 1,500 & dfrAl-aadA1 \\
\hline MWDC 2202 & 2 & - & - & 3 (MDR) & AM AMC STX & 2,500 & NT \\
\hline MWDC 2203 & 1 & - & + & 1 & $\mathrm{AM}$ & 800 & NT \\
\hline R3 5031 & 1 & + & + & 3 (MDR) & AM STX CIP LVX & 1,400 & NT \\
\hline \multicolumn{8}{|c|}{ VR (mouth of the Vistula River) } \\
\hline O4 2092 & 1 & + & + & 1 & $\mathrm{AM}$ & 1,000 & aadAl \\
\hline O4 5012 & 1 & + & + & 1 & $\mathrm{AM}$ & 1,000 & aadAl \\
\hline \multirow[t]{2}{*}{ O5 5017} & 1 & + & + & 2 & AM STX & 1,500 & dfrAl-aadA1 \\
\hline & 2 & & & & & 2,600 & est $X$-sat $2^{\mathrm{a}}$ \\
\hline UWWC 3001A & 1 & + & + & 4 (MDR) & AM AMC STX CIP LVX & 1,700 & NT \\
\hline UWWC 3001B & 1 & + & + & 4 (MDR) & AM AMC STX CIP LVX & 1,750 & NT \\
\hline O3 5008 & 1 & + & + & 3 (MDR) & AM AMC STX & 1,500 & NT \\
\hline
\end{tabular}

$A M$ ampicillin, $A M C$ amoxicillin/clavulanate, $A T M$ aztreonam, $C Z$ cefazolin, $C A Z$ ceftazidime, $C T X$ cefotaxime, $C X M$ cefuroxime, $F E P$ cefepime, $C I P$ ciprofloxacin, $L V X$ levofloxacin, $G M$ gentamicin, $N N$ tobramycin, TZP piperacillin/tazobactam, $S T X$ trimethoprim/sulfamethoxazole, $N T$ not tested, $M D R$ multidrug-resistance phenotype, ESBL extended-spectrum $\beta$-lactamase phenotype

${ }^{\text {a }}$ Only partial sequence was available

both groups of isolates, and none of the integron-negative isolates were resistant to amikacin. Resistance to fluoroquinolones (ciprofloxacin and levofloxacin), trimetho$\mathrm{prim} / \mathrm{sulfamethoxazole,} \mathrm{amoxicillin/clavulanate,} \mathrm{and}$ piperacillin/tazobactam was significantly associated with the presence of integrons (Fisher's exact test, $P<0.05$ for piperacillin/tazobactam, $P<0.01$ for the other abovementioned antibiotics).

Presence of integrons together with STX resistance is not surprising, since occurrence of sulfonamide resistance gene (sull) is often associated with classic class 1 integrons (Paulsen et al. 1993). Correlation of other resistance with integrons is likely to the presence of numerous resistance genes in one genetic element, e.g., plasmids or transposons
(Stalder et al. 2012). Similar findings were observed in heterotrophic bacteria isolated from Baltic Sea waters. In those strains, statistical analysis indicated relationships between resistance to some antibiotics (ampicillin and erythromycin, chloramphenicol and erythromycin, chloramphenicol and tetracycline, erythromycin and tetracycline), suggesting the linkage of resistance genes for antibiotics belonging to different classes (Moskot et al. 2012). No statistically significant differences were found for cephalosporins, carbapenems, aminoglycosides, and aztreonam, due to lack of or a small number of isolates resistant to those antibiotics in the study. The integronbearing isolates were resistant to $1-13$ of the tested antimicrobials belonging to $1-8$ classes, and $50 \%$ of those isolates were multidrug resistant (according to the definition proposed by 
Magiorakos et al. (2012)). Integron-negative isolates were resistant to 1-11 antimicrobials belonging to 1-7 classes and 17 of them $(10 \%)$ were multidrug resistant. The difference in the MDR phenotype frequency between isolates with and without integrons was statistically significant $(P<0.01$, Fisher's exact test). This is a common phenomenon, independent of species or origin of samples (Leverstein-van Hall et al. 2003). The differences in resistance ranges (number of antimicrobials or number of antimicrobial classes) between both groups of isolates were statistically significant $(P<0.001$, Mann-Whitney $U$ test).

Characteristics of class 1 and 2 variable regions and gene cassette arrays

E. coli isolates carrying the class 1 and 2 integrons (84 and 8 isolates, respectively) were further analyzed for the presence of inserted gene cassettes in the variable region using the primer sets 5CS-3CS and hepF-hepR (Table 1), designed to amplify variable region of integrons class 1 and 2, respectively. Among all class 1 integron-positive isolates, $57.14 \%(n=$ 48) possessed variable regions with size ranging from 650 to $2,600 \mathrm{bp}$. Among eight isolates bearing class 2 integrons, five isolates $(62.5 \%)$ had variable region with size ranging from 2,200 to 2,500 bp. Characteristics of those integron-bearing isolates are shown in Table 3.

In some integrase-positive isolates, variable regions were not detected (with standard primers 5CS and 3CS). The absence of gene cassettes in those isolates could be possible due to the presence of a cassette array that is too large to amplify (Partridge et al. 2009). Similar findings were also noted by Ndi and Barton (2011) and Yu et al. (2003). Since occurrence of sulfonamide resistance gene (sull) and quaternary ammonium compounds resistance gene ( $q a c \mathrm{E} \Delta 1)$ is often associated with classic class 1 integrons (Paulsen et al. 1993), in all
intI1-positive isolates, presence of those genes was tested. In 25 isolates (29.76\%), sull gene was not detected, and in 23 of those isolates, we failed to amplify the variable regions. In 21 isolates $(25 \%)$, qac $\mathrm{E} \Delta 1$ gene was not detected, and those isolates also did not possess variable regions. Similar findings were noted for $P$. aeruginosa (Nass et al. 1998) and E. coli (Sáenz et al. 2004). However, there were two isolates (WWDC 701 from WMOut and MWDC 2203 from DMOut, Table 2) in which we managed to amplify variable regions, despite the lack of sull gene and the presence of $q a c \mathrm{E} \Delta 1$ gene. There were also three isolates with mentioned above $3^{\prime}$ end of the integron, in which variable regions were not detected. Thus, we assume that in isolates without detectable variable regions, there are integrons with non-classic structure, probably with the tni region or various insertion sequences (IS), as mentioned by Partridge et al. (2009).

Among all integron-positive isolates, 48 isolates with class 1 integron and 5 isolates with class 2 integron contained variable regions (listed in Table 3), but only 35 selected amplicons were sequenced. Further analysis of the obtained sequences showed that the selected isolates harbored nine distinct gene cassette arrays (Table 4).

The most prevalent genes detected in variable regions of integrons were those connected with resistance to aminoglycosides ( $\operatorname{adA} A 1, \operatorname{aad} A 2$, and $\operatorname{aad} A 5)$ and trimetophrim (dfrA1, $d f r A 5, d f r A 7$, and $d f r A 17$ ). Those genes were present alone, as well as in combination with each other, or other resistance genes. Genes conferring resistance to streptothricin (est $X$ and sat2) were detected only in isolates bearing class 2 integron. One isolate, obtained from the mouth of the VR, harbored both classes of integrons, with gene cassette arrays: $d$ frA1aadA1 (class 1 integron) and est $X$-sat2 (class 2 integron). Similar patterns were detected in Aeromonas and Enterobacteriaceae strains isolated from slaughterhouse WWTP (Moura et al. 2007), in E. coli of human and animal

Table 4 Distribution of the different cassette arrays in E. coli isolates obtained from different sources

\begin{tabular}{|c|c|c|c|c|c|c|}
\hline \multicolumn{2}{|c|}{ Type of integron and gene cassette arrays } & \multirow[t]{2}{*}{ No. of isolates } & \multicolumn{4}{|c|}{ Source of isolates } \\
\hline Class 1 & Class 2 & & RW & TW & MOut & VR \\
\hline$d f r A 1-a a d A 1$ & - & 13 & 6 & 4 & 2 & 1 \\
\hline dfral7-aadA5 & - & 6 & 4 & 1 & 1 & - \\
\hline $\operatorname{aadAl}$ & - & 6 & 2 & 3 & - & 1 \\
\hline dfrA12-orfF-aadA2 & - & 3 & 3 & - & - & - \\
\hline- & $d f r A 1$-sat2-aadA1 & 3 & - & 2 & 1 & - \\
\hline$d f r A 7$ & - & 1 & - & - & 1 & - \\
\hline$d f r A 5$ & - & 1 & - & 1 & - & - \\
\hline$b l a_{\mathrm{OXA} 30^{-}}-a a d A 1$ & - & 1 & 1 & - & - & - \\
\hline$d f r A 1-a a d A 1$ & $e s t X$-sat $2^{\mathrm{a}}$ & 1 & - & - & - & 1 \\
\hline
\end{tabular}

$R W$ raw wastewater, $T W$ treated wastewater, MOut marine outfall of WWTPs, $V R$ mouth of the Vistula River

${ }^{a}$ Only partial sequence was available 
origin in Korea (Kang et al. 2005) and E. coli from Seine Estuary in France (Laroche et al. 2009). Among all sequenced variable regions of integrons, the most prevalent cassette arrays were dfrA1-aadA1, dfrA17-aadA5, and aadA1 (Table 4).

It is interesting to find that some patterns were found only in isolates from raw wastewater, like $d f r A 12$-orfF-aadA2 while others only in treated wastewater or marine outfalls of WWTPs ( $d f r A 5$ and $d f r A 7$, respectively) (Table 4).

\section{Conclusions}

Data obtained in this study indicated that wastewater treatment processes together with effective dilution of treated wastewater by marine outfall were generally sufficient to protect coastal water quality from sanitary degradation. However, human-associated bacteria, even potential pathogens and bacteria carrying antibiotic resistance genes of clinical significance, survived in wastewater and marine water conditions. Moreover, these resistant bacteria were enriched in highly diverse integrons, with nine different gene cassette arrays. Statistically significant association between resistance to fluoroquinolones, trimethoprim/sulfamethoxazole, amoxicillin/clavulanate, and piperacillin/tazobactam and the presence of integrons in $E$. coli isolates was noted. Integrons are clearly important for the development of the MDR phenotype. In conclusion, data obtained during this study indicate the potential of WWTP's effluents in facilitating horizontal gene transfer of mobile genetic elements and MDR phenotypes in the studied area. Given the similarity of WWTP processes and municipal wastewater composition, it is likely the common problem requiring further investigation.

Acknowledgments This work was supported by the Polish Ministry of Science and Higher Education (project no. NN 304202137 to EK and NN 305461139 to AL) and by the Institute of Oceanology, Polish Academy of Sciences (statutory task no. IV.4.2 to EK). The authors would like to thank A. Moura for valuable comments and suggestions to improve the quality of the paper.

Open Access This article is distributed under the terms of the Creative Commons Attribution License which permits any use, distribution, and reproduction in any medium, provided the original author(s) and the source are credited.

\section{References}

Andersson DI, Hughes D (2012) Evolution of antibiotic resistance at nonlethal drug concentrations. Drug Resist Update 15:162-172

APHA (1998) Standard methods for the examination of water and wastewater, 20th edn. American Public Health Association, Washington, DC

Baquero F, Alvarez-Ortego C, Martinez JL (2009) Ecology and evolution of antibiotic resistance. Environ Microbiol Rep 1:469-476

Bonfield JK, Smith KF, Staden R (1995) A new DNA sequence assembly program. Nucleic Acids Res 23:4992-4999
Boucher Y, Labbate M, Koenig JE, Stokes HW (2007) Integrons: mobilizable platforms that promote genetic diversity in bacteria. Trends Microbiol 15:301-309

Cambray G, Guerout A-M, Mazel D (2010) Integrons. Annu Rev Genet 44:141-166

Chagas TPG, Seki LM, Cury JC, Oliveira JAL, Davila AMR, Silva DM, Asensi MD (2011) Multiresistance, beta-lactamase-encoding genes and bacterial diversity in hospital wastewater in Rio de Janeiro, Brazil. J Appl Microbiol 111:572-581

Cocchi S, Grasselli E, Gutacker M, Benagli C, Convert M, Piffaretti J-C (2007) Distribution and characterization of integrons in Escherichia coli strains of animal and human origin. FEMS Immunol Med Microbiol 50:126-132

Czekalski N, Berthold T, Caucci S, Egli A, Bürgmann H (2012) Increased levels of multiresistant bacteria and resistance genes after wastewater treatment and their dissemination into Lake Geneva, Switzerland. Front Microbiol. doi:10.3389/fmicb.2012.00106

D’Costa VM, McGrann KM, Hughes DW, Wright GD (2006) Sampling the antibiotic resistome. Science 311:374-377

DIRECTIVE 2006/7/EC of the European Parliament and of the Council (2006) Concerning the management of bathing water quality and repealing Directive 76/160/EEC. http://eur-lex.europa.eu/ LexUriServ/LexUriServ.do?uri=OJ:L:2006:064:0037:0051:EN:PDF. Accessed July 2014

Dubois V, Parizano M-P, Arpin C, Coulange L, Bezian MC, Quentin C (2007) High genetic stability of integrons in clinical isolates of Shigella spp. of worldwide origin. Antimicrob Agents Chemother $51: 1333-1340$

ECDC (2010) Survivallence of antimicrobial consumption in Europe. http://www.ecdc.europa.eu/en/publications/Publications/ antimicrobial-antibiotic-consumption-ESAC-report-2010-data.pdf. Accessed July 2014

ECDC (2011) Antimicrobial resistance surveillance in Europe 2011. http://ecdc.europa.eu/en/publications/Publications/Forms/ECDC_ DispForm.aspx?ID=998. Accessed July 2014

ECDC/EMEA (2009) Joint technical report: the bacterial challenge: time to react. http://www.ecdc.europa.eu/en/publications. Accessed July 2014

Elsaied H, Stokes HW, Nakamura T, Kitamura K, Kamagata Y, Fuse H, Maruyama A (2007) Novel and diverse integron integrase genes and integron-like gene cassettes are prevalent in deep-sea hydrothermal vents. Environ Microbiol 9:2298-2312

Elsaied H, Stokes HW, Kitamura K, Kurusu Y, Kamagata Y, Maruyama A (2011) Marine integrons containing novel integrase genes, attachment sites, attI, and associated gene cassettes in polluted sediments from Suez and Tokyo Bays. ISME J 5:1162-1177

EUCAST (2011) The European Committee on Antimicrobial Susceptibility Testing. http://www.eucast.org/clinical_breakpoints/. Accessed July 2014

Falbo V, Carattoli A, Tosini F, Pezzella C, Dionisi AM, Luzzi I (1999) Antibiotic resistance conferred by a conjugative plasmid and a class I integron in Vibrio cholerae O1 El Tor strains isolated in Albania and Italy. Antimicrob Agents Chemother 43:693-696

Ferreira da Silva M, Vaz-Moreira I, Gonzalez-Pajuelo M, Nunes OC, Manaia CM (2007) Antimicrobial resistance patterns in Enterobacteriaceae isolated from an urban wastewater treatment plant. FEMS Microbiol Ecol 60:166-176

Galvin S, Boyle F, Hickey P, Vellinga A, Morris D, Cormican M (2010) Enumeration and characterization of antimicrobial-resistant Escherichia coli bacteria in effluent from municipal, hospital, and secondary treatment facility sources. Appl Environ Microbiol 76: 4772-4779

Gillings MR, Holley MP, Stokes HW (2009) Evidence for dynamic exchange of qac gene cassettes between class1integrons and other integrons in freshwater biofilms. FEMS Microbiol Lett 296:282-288 
Goldstein C, Lee MD, Sanchez S, Hudson C, Philips B, Register B, Grady M, Liebert C, Summers AO, White DG, Maurer JJ (2001) Incidence of class 1 and 2 integrases in clinical and commensal bacteria from livestock, companion animals, and exotics. Antimicrob Agents Chemother 45:723-726

Grape M, Sundström L, Kronvall G (2003) Sulphonamide resistance gene sul3 found in Escherichia coli isolates from human sources. J Antimicrob Ther 52:1022-1024

Guenther S, Ewers C, Wieler LH (2011) Extended-spectrum betalactamases producing $E$. coli in wildlife, yet another form of environmental pollution? Front Microbiol. doi:10.3389/fmicb.2011.00246

Gupta K, Hooton TM, Stamm WE (2005) Isolation of fluoroquinoloneresistant rectal Escherichia coli after treatment of acute uncomplicated cystitis. J Antimicrob Chemother 56:243-246

Harada K, Asai T (2010) Role of antimicrobial selective pressure and secondary factors on antimicrobial resistance prevalence in Escherichia coli from food-producing animals in Japan. J Biomed Biotechnol. doi:10.1155/2010/180682

Hartmann A, Locatelli A, Amoureux L, Depret G, Jolivet C, Gueneau E, Neuwirth C (2012) Occurrence of CTX-M producing Escherichia coli in soils, cattle, and farm environment in France (Burgundy Region). Front Microbiol. doi:10.3389/fmicb.2012.00083

Iwane T, Urase T, Yamamoto K (2001) Possible impact of treated wastewater discharge on incidence of antibiotic resistant bacteria in river water. Water Sci Technol 43:91-99

Kallen AJ, Welch HG, Sirovich BE (2006) Current antibiotic therapy for isolated urinary tract infections in women. Arch Intern Med 166: 635-639

Kang HY, Jeong YS, Oh JY, Tae SH, Choi CH, Moon DC, Lee WK, Lee YC, Seol SY, Cho DT, Lee JC (2005) Characterization of antimicrobial resistance and class 1 integrons found in Escherichia coli isolates from humans and animals in Korea. J Antimicrob Chemother 55:639-644

Koczura R, Mokracka J, Jablonska L, Gozdecka E, Kubek M, Kaznowski A (2012) Antimicrobial resistance of integron-harboring Escherichia coli isolates from clinical samples, wastewater treatment plant and river water. Sci Total Environ 414:680-685

Korzeniewska E, Korzeniewska A, Harnisz M (2013) Antibiotic resistant Escherichia coli in hospital and municipal sewage and their emission to the environment. Ecotox Environ Safe 91:96-102

Kraft CA, Timbury MC, Platt DJ (1986) Distribution and genetic location of Tn7 in trimethoprim-resistant Escherichia coli. J Med Microbiol 22:25-131

Laroche E, Pawlak B, Berthe T, Skurnik D, Petit F (2009) Occurrence of antibiotic resistance and class 1, 2 and 3 integrons in Escherichia coli isolated from a densely populated estuary (Seine, France). FEMS Microbiol Ecol 68:118-130

Leverstein-van Hall MA, Blok HEM, Donders ART, Paauw A, Fluit AC, Verhoef J (2003) Multidrug resistance among Enterobacteriaceae is strongly associated with the presence of integrons and is independent of species or isolate origin. J Infect Dis 187:251-259

Levesque C, Piche L, Larose C, Roy PH (1995) PCR mapping of integrons reveals several novel combinations of resistance genes. Antimicrob Agents Chemother 39:185-191

Li D, Yu T, Zhang Y, Yang M, Li Z, Liu M, Qi R (2009) Antibiotic resistance characteristics of environmental bacteria from an oxytetracycline production wastewater treatment plant and the receiving river. Appl Environ Microbiol 76:3444-3451

Liebana E, Carattoli A, Coque TM, Hasman H, Magiorakos AP, Mevius D, Peixe L, Poirel L, Schuepbach-Regula G, Torneke K, Torren-Edo J, Torres C, Threlfall J (2013) Public health risks of enterobacterial isolates producing extended-spectrum $\beta$-lactamases or AmpC $\beta$ lactamases in food and food-producing animals: an EU perspective of epidemiology, analytical methods, risk factors, and control options. Clin Infect Dis 56:1030-1037
Literak I, Dolejska M, Janoszowska D, Hrusakova J, Meissner W, Rzyska H, Bzoma S, Cizek A (2010) Antibiotic-resistant Escherichia coli bacteria, including strains with genes encoding the extendedspectrum beta-lactamase and QnrS, in waterbirds on the Baltic Sea coast of Poland. Appl Environ Microbiol 76:8126-8134

Łuczkiewicz A, Jankowska K, Fudala-Książek S, Olańczuk-Neyman K (2010) Antimicrobial resistance of fecal indicators in municipal wastewater treatment plant. Water Res 44:5089-5097

Ma L, Zhang X-X, Zhao F, Wu B, Cheng S, Yang L (2013) Sewage treatment plant serves as a hot-spot reservoir of integrons and gene cassettes. J Environ Biol 34:391-399

Magiorakos A-P, Srinivasan A, Carey RB, Carmeli Y, Falagas ME, Giske CG, Harbarth S, Hindler JF, Kahlmeter G, Olsson-Liljequist B, Paterson DL, Rice LB, Stelling J, Struelens MJ, Vatopoulos A, Weber JT, Monnet DL (2012) Multidrug resistant, extensively drug-resistant and pandrug-resistant bacteria: an international expert proposal for interim standard definitions for acquired resistance. Clin Microbiol Infect 18:268-281

Mammeri H, Van De Loo M, Poirel L, Martinez-Martinez L, Nordmann P (2005) Emergence of plasmid-mediated quinolone resistance in Escherichia coli in Europe. Antimicrob Agents Chemother 49:71-76

Martinez JL (2008) Antibiotics and antibiotic resistance genes in natural environments. Science 321:365-367

Mazel D, Dychinco B, Webb VA, Davies J (2000) Antibiotic resistance in the ECOR collection: integrons and identification of a novel aad gene. Antimicrob Agents Chemother 44:1568-1574

Mokracka J, Koczura R, Kaznowski A (2012) Multiresistant Enterobacteriaceae with class 1 and class 2 integrons in a municipal wastewater treatment plant. Water Res 46:3353-3363

Moskot M, Kotlarska E, Jakóbkiewicz-Banecka J, Gabig-Cimińska M, Fari K, Wegrzyn G, Wróbel B (2012) Metal and antibiotic resistance of bacteria isolated from the Baltic Sea. Int Microbiol 15:131-139

Moura A, Henriques I, Rieiro R, Correia A (2007) Prevalence and characterization of integrons from bacteria isolated from a slaughterhouse wastewater treatment plant. J Antimicrob Chemother 60:1243-1250

Moura A, Soares M, Pereira C, Leitão N, Henriques I, Correia A (2009) INTEGRALL: a database and search engine for integrons, integrases and gene cassettes. Bioinformatics 25:1096-1098

Moura A, Pereira C, Henriques I, Correia A (2012) Novel gene cassettes and integrons in antibiotic-resistant bacteria isolated from urban wastewaters. Res Microbiol 163:92-100

Nass T, Sougakof W, Casetta A, Nordmann P (1998) Molecular characterization of OXA-20, a novel class D $\beta$-lactamase, and its integron from Pseudomonas aeruginosa. Antimicrob Agents Chemother 42: 2074-2083

Ndi OL, Barton MD (2011) Incidence of class 1 integron and other antibiotic resistance determinants in Aeromonas spp. from rainbow trout farms in Australia. J Fish Dis 34:589-599

Novo A, Manaia CM (2010) Factors influencing antibiotic resistance burden in municipal wastewater treatment plants. Appl Microbiol Biotechnol 87:1157-1166

Pan J-C, Ye R, Meng D-M, Zhang W, Wang H-Q, Liu K-Z (2006) Molecular characteristics of class 1 and 2 integrons and their relationship to antibiotic resistance in clinical isolates of Shigella sonnei and Shigella flexneri. J Antimicrob Chemother 58:288-296

Partridge SR, Tsafnat G, Coiera E, Iredell JR (2009) Gene cassette and cassette arrays in mobile resistance integrons. FEMS Microbiol Rev 33:757-784

Paulsen IT, Littlejohn TG, Rådström P, Sundström L, Sköld O, Swedberg G, Skurray RA (1993) The 3' conserved segment of integrons contains a gene associated with multidrug resistance to antiseptics and disinfectants. Antimicrob Agents Chemother 37:761-768

Perez F, Endimiani A, Hujer KM, Bonomo RA (2007) The continuing challenge of ESBLs. Curr Opin Pharmacol 7:459-469 
Pitout JDD, Nordmann P, Laupland KB, Poirel L (2005) Emergence of Enterobacteriaceae producing extended-spectrum $\beta$-lactamases (ESBLs) in the community. J Antimicrob Chemother 56:52-59

Poirel L, Cattoir V, Nordmann P (2012) Plasmid-mediated quinolone resistance; interactions between human, animal, and environmental ecologies. Front Microbiol. doi:10.3389/fmicb.2012/00024

Recchia GD, Hall RM (1995) Gene cassettes: a new class of mobile element. Microbiology 141:3015-3027

Reinthaler FF, Posch J, Feierl G, Wust G, Haas D, Ruckenbauer G, Mascher F, Marth E (2003) Antibiotic resistance of E. coli in sewage and sludge. Water Res 37:1685-1690

Reinthaler FF, Feierl G, Galler H, Haas D, Leitner E, Mascher F, Melkes A, Posch J, Winter I, Zarfel G, Marth E (2010) ESBL-producing E. coli in Austrian sewage sludge. Water Res 44:1981-1985

Rosser SJ, Young H-K (1999) Identification and characterization of class 1 integrons in bacteria from aquatic environment. J Antimicrob Chemother 44:11-18

Sáenz Y, Briñas L, Domínguez E, Ruiz J, Zarazaga M, Vila J, Torres C (2004) Mechanisms of resistance in multiple-antibiotic resistant Escherichia coli strains of human, animal, and food origins. Antimicrob Agents Chemother 48:3996-4001

Sambrook J, Russell DW (2001) Molecular cloning: a laboratory manual, 3rd edn. Cold Spring Harbour Laboratory Press, Cold Spring Harbour, New York

Smet A, Martel A, Persoons D, Dewulf J, Heyndrickx M, Herman L, Haesebrouck F, Butaye P (2010) Broad-spectrum beta-lactamases among Enterobacteriaceae of animal origin: molecular aspects, mobility and impact on public health. FEMS Microbiol Rev 34:95-316

Stalder T, Barraud O, Casellas M, Dagot C, Ploy M-C (2012) Integron involvement in environmental spread of antibiotic resistance. Front Microbiol. doi:10.3389/fmicb.2012.00119

Stokes HW, Hall RM (1989) A novel family of potentially mobile DNA elements encoding site-specific gene-integration functions: integrons. Mol Microbiol 3:1669-1683
Su J, Shi L, Yang L, Xiao Z, Li X, Yamasaki S (2006) Analysis of integrons in clinical isolates of Escherichia coli in China during the last six years. FEMS Microbiol Lett 254:75-80

Tausova D, Dolejska M, Cizek A, Hanusova L, Hrusakova J, Svoboda A, Camlik G, Literak I (2012) Escherichia coli with extended-spectrum $\beta$-lactamase and plasmid-mediated quinolone resistance genes in great cormorants and mallards in Central Europe. J Antimicrob Chemother 67:1103-1107

Tchobanoglous G, Burton FL, Metcalf \& Eddy (1991) Wastewater engineering: treatment, disposal, and reuse, 3rd edn. McGraw-Hill, New York

Vinue L, Saenz Y, Somalo S, Escudero E, Moreno MA, RuizLarrea F, Torres C (2008) Prevalence and diversity of integrons and associated resistance genes in faecal Escherichia coli isolates of healthy humans in Spain. J Antimicrob Chemother 62:934-937

White PA, MacIver CJ, Rawlinson WD (2001) Integrons and gene cassettes in the Enterobacteriaceae. Antimicrob Agents Chemother 45:2658-2661

Xia R, Ren Y, Guo X, Xu H (2013) Molecular diversity of class 2 integrons in antibiotic-resistant gram-negative bacteria found in wastewater environments in China. Ecotoxicology 22:402-414

Xu Z, Li L, Shi L, Shirtliff ME (2001) Class 1 integron in staphylococci. Mol Biol Rep 38:5261-5279

$\mathrm{Xu} \mathrm{Z,} \mathrm{Li} \mathrm{L,} \mathrm{Shirtliff} \mathrm{ME,} \mathrm{Peters} \mathrm{BM,} \mathrm{Peng} \mathrm{Y,} \mathrm{Alam} \mathrm{MJ,}$ Yamasaki S, Shi L (2010) First report of class 2 integron in clinical Enterococcus faecalis and class 1 integron in Enterococcus faecium in South China. Diagn Microbiol Infect Dis 68:315-317

Yu HS, Lee JC, Kang HY, Ro DW, Chung JY, Jeong YS, Tae SH, Choi CH, Lee EY, Seol SY, Lee YC, Cho DT (2003) Changes in gene cassettes of class 1 integrons among Escherichia coli isolates from urine specimens collected in Korea during the last two decades. J Clin Microbiol 41:5429-5433 